\title{
Forskning om \\ konsumtionsvillkor för \\ hushåll med knapp ekonomi \\ - ett svagt utvecklat fält
}

\author{
TORBJÖRN HJORT
}

\begin{abstract}
I denna artikel diskuteras och problematiseras nordisk forskning med in riktning mot konsumtion och fattigdom.

Då forskningen inom detta fält förekommer inom flera vetenskapliga discipliner beskrivs några centrala perspektiv. Härefter problematiseras befintlig forskning, såväl $i$ förhållande till dess innehaill som till dess hitintills svaga etablering. Vidare ges förslag på utvecklingsmöjligheter.
\end{abstract}

\section{Inledning}

Inom nordisk fattigdomsforskning är konsumtion en aspekt som inte belysts i speciellt hög grad. Efter en samhällsekonomisk nedgång under 1990-talet tenderar samhällsekonomin och välfärden återigen att utvecklas i en positiv riktning. Detta gäller för en majoritet av befolkningen. För vissa grupper pekar däremot utvecklingen i en mer negativ riktning, relativt sett. De grupper som under 1990-talet halkat efter

Torbjörn Hjort är fil dr i socialt arbete och verksam vid Socialhögskolan, Lunds universitet och Institutionen för vårdvetenskap och socialt arbete (IVOSA), Växjö universitet. består i huvudsak av ensamstående föräldrar (huvudsakligen kvinnor), ungdomar och förhållandevis nyanlända invandrare (SOU 2000). En annan betydande samhällsutveckling, dock i ett längre tidsperspektiv, hänger samman med konsumtionens förändrade och allt mer påtagliga betydelse (Gabriel \& Lang 1995, Bauman 1998, Baudrillard 1998). För det första har konsumtionsförhållandena förändrats i så motto att varor och tjänster idag blir alltmer lätttillgängliga, utbudet ökar och marknadsföringen tar en allt större plats bland annat genom sin sammanblandning med medier och kulturindustrin (se t.ex. Jansson 2001). För det andra har sätten att konsumera 
utvecklats såväl gällande själva köpet som finansieringen av detta. Kreditmarknaden har expanderat. Nya alternativ som hyrköp och leasing utvecklas. Avregleringar av exempelvis telefoni och energi samt möjligheter till näthandel är bara några exempel på hur förutsättningarna för konsumtion förändrats. För det tredje tycks det även vara så att våra konsumtionsvanor betyder allt mer för hur vi uppfattas av vår omgivning. Konsumtionens symboliska värde tenderar att öka i takt med att vi i allt större utsträckning omges av budskap om vad och hur vi bör konsumera genom exempelvis marknadsföring och medier som på olika sätt förmedlar en bild av vilken mat vi ska äta, hur vi ska inreda våra hem, vart vi ska resa, hur vi ska klä oss, vilken hemelektronik vi ska välja etc. (Slater \& Tonkiss 2001). Det råder emellertid delade meningar om hur betydelsefull varors och tjänsters symboliska betydelse är i förhållande till deras funktionella betydelse (se t.ex. Leiss et al. 2000, Jansson 2001 ).

Mot bakgrund av dessa utvecklingstrender finns det anledning att ställa frågor om hur ekonomiskt sårbara grupper påverkas av förändrade förutsättningar för konsumtion. Finns det risker att olika konsumtionsvillkor, dvs. prissättning, tillgänglighet, karaktären på erbjudanden och rabatter, kostnader för och möjligheter till kredit etc., ytterligare förstärker en knapp och utsatt position?

Inom amerikansk och till viss del inom brittisk forskning föreligger ett antal studier om förhållandet mellan ekonomisk knapphet och konsumtion. Alltsedan Caplovitz berömda bok "The poor pay more" (1963) har man inom amerikansk forskning ur olika perspektiv visat på hur hushåll med knapp ekonomi utestängts och diskriminerats som konsumenter jämfört med andra mer etablerade inkomstgrupper (se t.ex. Andreasen 1975, 1993, Kaufman et al. 1997, Hill 2002, Allwitt \& Donley 1996, Allwitt 1996). ${ }^{1}$ Inom Norden är emellertid denna forskning svagt utvecklad, det finns egentligen inga studier som specifikt fokuserar konsumtionsvillkor för hushåll med knapp ekonomi (Löfgren 1996, Hjort 2000). ${ }^{2}$ Det finns dock en förhållandevis rik flora av studier som på olika sätt närmar sig detta forskningsproblem. I denna artikel har jag för avsikt att närmare granska nordisk forskning som diskuterar knapp ekonomi och konsumtion. Vidare ska jag diskutera hur det kan komma sig att vi inte kan finna någon nordisk motsvarighet till den amerikanska forskningstraditionen. Jag tar min utgångspunkt i en aktuell kunskapsöversikt (Hjort 2000).

\section{Nordisk forskning}

De två vetenskapliga fält som ska mötas och förstås i förhållande till varandra är forskning om fattigdom och forskning om konsumtion. Inom Norden finns en relativt väl utvecklad forskningstradition som foku-

1 För en genomgång av hur moral har knutits till de fattigas konsumtion ur ett mer historisk perspektiv se Horowitz (1985).

2 Jag vill dock påpeka att Kommittén för välfärdsbokslutet gav Dellgran \& Karlsson (se SOU 2001) i uppdrag att skriva en text kring konsumtion ur ett mer fördelningspolitiskt perspektiv. Möjligen kan detta ses som ett tecken på att detta fält börjar bli intressant för välfärdsforskningen. 
serar på fattigdomens utbredning, orsaker och avtryck i människors vardag. När det gäller konsumtions- eller konsumentforskning är denna besvärligare att få ett klart grepp om. Ofta bedrivs konsumtionsrelaterad forskning från tvärvetenskapliga utgångspunkter och inom flera olika discipliner, vilket bland annat innebär att resultaten är svåra att hitta då etiketteringen ser olika ut inom olika discipliner. ${ }^{3}$

De olika vetenskapliga disciplinerna studerar kunskapsobjektet konsumtion ur flera olika perspektiv vilka ibland överlappar varandra. Det går dock att urskilja eller konstruera vissa kategorier. Ett försök till uppdelning är att avgränsa forskning som betonar producentsidan i förhållande till konsumentsidan. En annan kategoriseringsmöjlighet är att skilja konsumentforskning som har tyngdpunkten på ekonomiska förhållanden från forskning som studerar konsumtion som ett samhällsfenomen utifrån olika gruppers konsumtionsmönster. En tredje variant utgörs av att skilja ut mikroorienterad forskning från ett mer övergripande strukturellt perspektiv. Några enkla generaliseringar gällande vilken forskningsdisciplin som anlägger vilket perspektiv låter sig inte göras, inom en och samma disciplin kan flera perspektiv vara möjliga.

En problematik som i princip all konsumtionsforskning har gemensam är att den inom sina respektive discipliner haft svårigheter att etablera sig som ett självständigt

3 Ett försök att samla de utspridda resurser som ändå finns gällande konsumtionsforskning är bildandet av konsumentforskningsnätverket FIK ur vilket även centrat CFK bildats, se www. cfk.gu.se. forskningsområde. Ett resultat av detta är att konsumtionen inte lyckats etablera sig som en självständig forskningsdisciplin. Under 1960- och 1970-talet rådde en viss polarisering där den mer företagsekonomiskt inriktade konsumentforskningen representerade "producentsidan" och beskylldes för att gå näringslivets ärenden. Det syftades då på studier av t.ex. lämpliga marknadsföringsmetoder, kund- eller konsumentundersökningar i syfte att lära sig hur dessa "tänkte» och med psykologins hjälp försöka förstå hur presumtiva kunder agerade och reagerade på olika signaler från producentledet. Enkelt uttryckt ansågs denna form av konsumentforskning ha till syfte att hjälpa näringslivet gällande kartläggningar av möjliga kunder. Den andra sidan representerades av kulturvetare och sociologer som beskylldes för att vara konsumtionsfientliga och delvis ha som forskningssyfte att "skydda" konsumenter från näringslivets metoder. Diskussioner om reklam, kommersialisering av ungdomskulturer, konsumtionssamhällets fördelar och nackdelar stod på dagordningen (se t.ex. Löfgren 1996, SOU 1996).

\section{Metod}

Kunskapsöversikten bygger för det första på sökningar i olika databaser som är uppbyggda kring nordiska universitets- och forskningsbibliotek. De databaser som huvudsakligen använts är Libris, såväl gällande litteratursökningar som dess artikeldatabas, Artikelsök, Econlit, Eric, Sociofile samt olika nordiska artikeldatabaser. Jag har sökt material med hjälp av sökbegrepp som consumption/low-income, consumption/ 
poverty, household/consumption, household/poverty samt en lång rad andra kombinationer med hjälp av såväl engelska som svenska/nordiska begreppskombinationer. Träffarna har tagits fram för att kontrollera huruvida de har haft någon nordisk anknytning och vidare om de haft någon relevans för denna kunskapsöversikt, d.v.s. att studierna haft ansatser mot att försöka undersöka relationen mellan ekonomisk knapphet och konsumtion.

För det andra har de olika universitetens hemsidor undersökts. Jag har utgått från relevanta fakulteter och institutioner för att få en uppfattning om det förekommer någon forskning inom det aktuella området. De namn, projekt och titlar som varit intressanta har sedan körts i de ovan nämnda databaserna. Det finns vidare två forskningscentra, SIFO (Statens Institutt for forbruksforskning) i Norge och NCRC (National Consumer Research Centre) i Finland, med inriktning mot konsumentforskning. Dessa har varit till hjälp i orienteringsarbetet.

För det tredje har jag undersökt de statliga verk och myndigheter, i respektive land, som kan tänkas ha kopplingar till området konsumtion/fattigdom. Publikationslistor, länkar, pressreleaser etc. har undersökts. I Sverige är t.ex. Konsumentverket en aktör som initierar, finansierar och publicerar forskning.

\section{Fem forskningstema}

Vad händer då när fattigdomsforskningen närmar sig konsumtionsforskningen och vice versa? Under fem teman kommer jag att presentera fem olika perspektiv som anlagts avseende forskning om ekonomiskt utsatta hushåll relaterat till konsumtion. Temana är inte självklart avgränsbara och häktar på olika sätt i varandra. Deras huvudfokus skiljer sig emellertid åt. De två första temana är inriktade mot samhällsinterventioner och de tre senare utgår från ett hushållsperspektiv.

\section{Schablonvarukorgoch hushällsbudget}

Ett första tema diskuterar hur konsumentpolitik i form av framtagandet av standardbudgetar och standardvarukorgar förhåller sig nivåmässigt till olika typer av offentliga välfärdslösningar. Syftet är bland annat att försöka skapa en norm för vad som ska karakteriseras som nödvändig konsumtion, vad ett hushåll behöver. Här ingår produktionen av statistik i syfte att följa prisutvecklingen bland annat i syfte att möjliggöra prisjämförelser och ge kunskaper om hur prisutvecklingen ser ut inom olika områden. Utifrån denna statistik konstrueras schablonvarukorgar och genomsnittliga hushållsbudgetar för olika hushållstyper. Dessa schablonkonstruktioner har betydelse när det gäller fastställande av existensminimum, förbehållsbelopp, socialbidragsnorm etc. Det handlar om att försöka hitta en nivå för vad som ska räknas som skäligt eller rimligt i konsumtionshänseende. Schablonberäkningarna ska vidare vara en hjälp inom ekonomisk rådgivning.

Hur förhåller sig då dessa standardbudgetar till de belopp som hushåll med knapp ekonomi har att leva av? Aatola och Viinsaalo (1995a) konstaterar att kostnaderna utifrån en standardbudget för en barnfa- 
milj låg över socialbidragsnivån i Finland. I en jämförelse med andra nordiska länder framkom det att det fanns skillnader mellan vad som karakteriseras som rimlig konsumtion. Den svenska utformningen låg ungefär på samma nivå som Finland. Norge hade en något högre nivå för vad som ingick i rimlig konsumtion och Danmark var det land som hade den minst detaljreglerade standardbudgeten. I en annan rapport (Aatola \& Viinsaalo 1995b) diskuterar författarna bakgrunden för definitioner av rimlig konsumtion utifrån sociala normer, rekommendationer och åsikter hos såväl experter som allmänhet. För att kunna mäta rimlig konsumtion används metoder från fattigdomsforskningen. Vidare beskrivs användningen av konceptet rimlig konsumtion i länderna Norge, Sverige, Danmark och Storbritannien. Författarna pekar på de problem som sammanhänger med användningen av standardbudgetar i förhållande till bidrag. Det handlar bland annat om att nivåerna på bidragen är så låga att det är svårt att göra någon förändring av konsumtionsmönstret, eller med andra ord finns det inte mer att spara in på. Då bidragstiden är tänkt att vara under kortare perioder finns inget utrymme för någon hushållsekonomisk planering eller långsiktig konsumtion. Vidare menar författarna att stödet som endast innebär pengar skulle kunna kompletteras med kunskaper och information.

\section{Skuldproblematik}

Ett andra tema som berör konsumtion och ekonomisk knapphet belyser skuldproblematik och de verksamheter som hanterar skuldsanering och budgetrådgivning. Skuld- problematik är att betrakta som en betydelsefull aspekt av knapphetens konsumtionsvillkor (Dellgran \& Karlsson 2001). Nordisk forskning om skuldsanering och ekonomisk rådgivning uppehåller sig huvudsakligen på tre nivåer. För det första en mer övergripande juridisk och ekonomisk nivå där implementeringsproblematik, kostnader, tolkningar och utfall av skuldsaneringslagen studeras. ${ }^{4}$ För det andra studeras de verksamheter som på olika sätt är aktörer gällande skuldsanering: socialtjänst, domstol och kronofogdemyndigheten. ${ }^{5}$ Denna forskning är inriktad på procedurfrågor, organisatoriska frågor samt uppföljningar och utvärderingar. För det tredje studeras skuldsanering på hushållsnivå: vilka erbjuds skuldsanering, hur är det att leva på existensminimum, är skuldsanering till någon hjälp är några exempel på frågor som ställs.

När det gäller orsakerna till att hushåll hamnar i »skuldfällan" ser förklaringarna olika ut. Skiljelinjen går, grovt sett, mellan att förstå orsakerna som individuellt respektive strukturellt betingade. Vidare handlar detta om vilka grupper som får skuldproblem. Dellgran (2000) menar att ett allt för individualistiskt perspektiv där socioekonomiska och strukturella faktorer tonas ner förlorar fördelningspolitiska dimensioner. Att konsumera genom kre-

4 Se t.ex. Aatola $(1992,1996)$.

5 Se t.ex. Poppe (1995). Poppe bedriver vid SIFO forskning om skuldsanering och ekonomisk rådgivning. Andra exempel på forskning vid SIFO inom detta område är Warstad (1994, 1995), Tufte (1992, 1993). Även vid forskningscentrat NCRC i Finland bedrivs forskning kring skuldsanering.

Torbjörn Hjort: Forskning om konsumtionsvillkor för hushåll... 
diter innebär att man intecknar framtida inkomster varför denna typ av konsumtion till viss del kan karakteriseras som "riskkonsumtion", åtminstone vad gäller grupper med knapp ekonomi med en förhållandevis svag etablering på arbetsmarknaden (SOU 2001).

Forskning med inriktning mot skuldsanering överlappar till viss del forskning om hushållsekonomisk rådgivning eller budgetrådgivning. Resultat visar att hushållen är nöjda med avtalet, d.v.s. att de blir av med skulderna, men att de fortfarande har problem med att få ekonomin att gå ihop (Klingander 1995). I en senare studie visar Klingander (1998) att hälften av hushållen i ett ingångsläge hade för låga inkomster för att klara så kallade skäliga utgifter. För huvuddelen av dessa hushåll förändrades inte detta förhållande under rådgivningen:

Detta har rådgivarna ingen möjlighet att påverka. Vad man kunnat göra är att hjälpa hushållen att överklaga beslut om bidragsnivåer. För de flesta är det emellertid en fråga om för låg disponibel inkomst som omöjliggör för hushaillen att klara av sin ekonomiska situation. För hushaill med sämst försörjningssituation hjälper inte ekonomisk rådgivning. (ibid, s 48)

Det förekommer kritik, bland annat från socialarbetare, som innebär att hushållsekonomisk rådgivning skulle vara moraliskt behäftad och kunna uppfattas som förmynderi och kontroll av fattiga och svaga grupper - att lära den fattige att vara fattig (Dellgran 2000). Löfgren (1996) menar att denna moraliska dimension inte är något nytt fenomen, den häktar i en annan »klassisk» dis- kussion som handlar om vad den fattige bör kunna unna sig respektive avstå ifrån.

\section{Konsumtion som välfärdsindikator}

Ett tredje tema diskuterar konsumtionsaspekter ur ett mer övergripande välfärdsperspektiv. Intresset riktas inte mot samhälleliga interventioner utan snarare mot att försöka förstå människors levnadsförhållande med fokus på ekonomiskt utsatta grupper. Här finner vi studier om olika gruppers konsumtionsmönster i förhållande till samhällsekonomiska svängningar (se t.ex. Wilska 1995). Vidare ställs frågor som vad som är den genomsnittliga konsumtionen, vad människor spenderar sina pengar på och var nivån ligger för basal eller nödvändig konsumtion. Kosunen (1999) visar att socialbidraget täcker den nödvändiga konsumtionen (boende, mat, kläder, sjukvård) hos samtliga hushållstyper. Vidare visar hans studie att de socialbidragsberoende hushållen spenderade, relativt sett, mindre pengar på nödvändig konsumtion än grupper med högre inkomster då socialbidraget även skulle täcka annan konsumtion. Kosunen menar att man kan ifrågasätta om det som räknas som nödvändig konsumtion i förhållande till socialbidraget är relevant. Kanske behöver innehållet i begreppet nödvändig konsumtion breddas och nyanseras.

Stjernö (1985) försöker ge en mer flerdimensionell bild av fattigdomen på såväl mikro- som makronivå. Han problematiserar hushållsekonomin (konsten att hålla en hushållsbudget) i så motto att han pekar på de strukturella problem hushåll med knapp ekonomi möter, t.ex. risken att få betala 
mer och få mindre och omgivningens fördomar. Emellertid fördjupas resonemangen kring konsumtionsvillkor inte.

När det gäller att förstå de inbördes relationerna mellan välfärd, fattigdom och konsumtion hjälper oss Halleröd (1995, 1998) genom att använda konceptet »konsensuell fattigdom" som utgångspunkt för statistiska studier. Konsensuell fattigdom är en fattigdomsdefinition som utgår från vad ett representativt urval av befolkningen anser vara nödvändigheter i form av varor, tjänster och aktiviteter. Därefter ställs frågor om vilka av varorna och tjänsterna som konsumeras och huruvida ett nekande svar beror på brist på pengar eller val. Metoden har fördelen att den mäter fattigdom relativt vad som anses rimligt av befolkningen i allmänhet. Hans resultat visar bland annat att konsumtionsdimensionen spelar en betydelsefull roll i förhållande till hur fattigdom definieras. Att enbart utgå från inkomst som mått innebär att flera dimensioner av vad det kan innebära att leva under ekonomisk knapphet går förlorade, däribland konsumtion. Kunskaper från denna typ av undersökningar ger oss en god bild av hur inkomstskillnader påverkar konsumtionsmöjligheter för olika grupper. Däremot får vi inte veta något om kvaliteten på de varor eller tjänster som konsumeras eller under vilka villkor konsumtionen sker. När det gäller t.ex. frågan om hushållet kan köpa presenter till familj och nära vänner vid högtidsdagar så hamnar två hushåll, där det ena har möjlighet att köpa en ny cykel till sin son och det andra en målarbok, i samma svarskategori.

\section{Hushaillsekonomiska balansproblem}

I ett fjärde tema kopplas konsumtion och ekonomisk knapphet till varandra genom resonemang med fokus på hushållsekonomiska balansproblem och hur hushållen hanterar problem med att få inkomster och utgifter att gå ihop med en knapp ekonomi. Här vill jag lyfta fram Brusdals (1988a, 1988b) undersökningar om hushållens hantering av knappa ekonomiska förhållanden. Den ena studien (1988: b), av huvudsakligen kvantitativ karaktär, behandlar hushållens beredskap för ekonomiska kriser, t.ex. arbetslöshet, skilsmässa och sjukdom. Två former av beredskap diskuteras: den formella och den informella. Den formella består av försäkringar, sparade medel, bankkontakter och den informella av nätverket som bildas av släkt, vänner, grannar etc. Studien visar den ökade vikten av den formella beredskapen, detta av olika skäl:

"Materialet viser at de fleste hushold vil kontakte bank og andre instanser framfor familien når det var behov for lån, og også ved betalningskrise hade de fleste ordnet opp på annen måte enn ved å trekke veksler på familien. Dreiningen mot den formelle og oppnådde beredskapen kan sees $i$ lys av samfunnsutviklingen, med ökende vekt på pengeökonomi, og hvor det etterhvert trengs store belöp for å drive et hushold. Skal husholdet klare å takle ulike ökonomiske vansker, er penger, og mange penger sentralt. I disse tilfellene blir den tilskevne og uformelle delen av beredskapen mindre viktig, fordi det er få familier som kan stille til rådighet

Torbjörn Hjort: Forskning om konsumtionsvillkor för hushåll... 
de belöp det vil vaere snakk om." (ibid. s. 97-98)

I den andra studien (1988a) beskriver Brusdal utifrån en intervjuundersökning olika strategier som hushållen använder sig av vid ekonomiska bekymmer. En uppdelning sker mellan tillfälliga och mer permanenta ekonomiska problem. Ju längre tid knappheten hade varat desto mer sårbar var ett hushåll för ytterligare påfrestningar. Resultatet visade på fyra huvudstrategier: den första strategin är att skaffa mer pengar, vilket kunde ske genom lån, gåvor, höjd arbetsinkomst och vidareutbildning. Den andra strategin är att leva mer sparsamt, t.ex. genom att göra upp en budget.

Brusdal menar att strategin att leva mer sparsamt bäst kan användas av de som »har det litt romslig i utgangspunkten", d.v.s. de som inte lever under svår knapphet. För de mest utsatta grupperna är denna strategi svår då det från början inte finns någon större elasticitet i budgeten.

Den tredje huvudstrategin innebär att varor och tjänster införskaffas till en rimligare kostnad, eller om möjligt, gratis. Denna strategi handlar mycket om de informella hjälpsystemen, t.ex. hjälp med pengar och saker från familj, släkt och vänner eller hjälp med hushållsarbete och barnpassning för att frigöra tid för extraarbete för att öka inkomsten. Den sista strategin är att söka socialbidrag.

\section{Intrafamiljär resursfördelning}

Det femte temat som förhåller sig till ekonomisk knapphet och konsumtion fokuse- rar på vad som händer inom hushållet när det gäller hur resurserna fördelas. Vid studier om ekonomisk utsatthet är det vanligt att hushållet utgör undersökningsobjektet. Detta har emellertid visat sig vara problematiskt, det är inte givet att olika medlemmar i ett hushåll har samma uppfattning om resursfördelningen. Att hushållet utgjort undersökningsobjektet grundar sig enligt Nyman (1996) huvudsakligen på två antaganden. För det första att resursfördelningen inom hushållet är jämnt fördelad och att levnadsstandarden och konsumtionen fördelas lika över hushållets medlemmar. Detta skulle innebära att fattigdom och deprivation enbart kan upplevas av personer tillhörande fattiga hushåll. Det andra antagandet grundar sig på föreställningen att hushållet agerar på samma sätt som en individ, forskningen har inte beaktat möjligheterna till konflikter och intressemotsättningar inom hushållet. Nyman pekar i sin studie på skillnader som förekommer mellan kvinnor och män inom hushållet. Även om skillnaderna inte är påtagliga är det viktigt att forskningen i fortsättningen beaktar de skillnader som ändå förekommer. Vidare har Bonke (1997) genom en intervjuundersökning kunnat identifiera fyra intrafamiljära fördelningsmodeller. 1) Den ensidiga fördelningsmodellen där kvinnan har allt ansvar för hushållsekonomin, mannen ger kvinnan större delen av sin lön och behåller endast en liten del för personliga utgifter. 2) Den andra fördelningsmodellen utgörs av att mannen ger kvinnan ett fast belopp varje månad till inköp av dagligvaror, medan resten av inkomsten stannar i detta så kallade husholdningspengesystem där mannen ansvarar för betalning 
av varor och tjänster. 3) Den gemensamma fördelningsmodellen, innebär att samtliga inkomster läggs i en pott som båda har tillgång till även om de kan vara ansvariga för olika hushållsutgifter. 4) Den individuella fördelningsmodellen innebär att var part behåller och förvaltar sin egen inkomst. Ingen av parterna har således tillgång till hela hushållets inkomst. I de hushåll som ingår i studien har i princip samtliga arbete, även om kvinnan arbetar deltid i några fall. Det är följaktligen inte tal om någon uttalad ekonomisk utsatthet, även om frågor ställs kring strategier vid avsaknad av pengar.

Inom ramen för detta tema ingår även resonemang med inriktning mot barnens betydelse och inflytande när det gäller familjeekonomin och konsumtion. Ekström (1995) visar att barns påverkansmöjligheter ökar i takt med att föräldrarnas socioekonomiska förhållanden förbättras. Näsman (1996, 1999, 2001a, 2001b) har studerat barns tankar om pengar och visar bland annat barns medvetenhet om hushållets ekonomiska situation samt att de på olika sätt försöker ta aktiv del när det gäller att förbättra en problematisk situation.

\section{Vad kan utvecklas?}

Den kunskap som finns belyser ekonomisk knapphet i relation till konsumtion ur flera olika perspektiv. Som jag nämnt tidigare är denna kunskap dock förhållandevis svagt utvecklad. Nedan kommer jag, genom att identifiera fyra huvuddrag, att problematisera befintlig forskning på området. Vidare kommer jag att peka på outforskade fält och ge några förslag på vilken typ av ny kunskap som kan berika detta område.
Ett första huvuddrag är att en stor del av forskningen utgår från makronivån och kvantitativa data. Norden, och kanske framför allt Sverige, är nästintill världsledande när det gäller statistisk information om befolkningen. Detta är en stor tillgång för forskningen och genererar kunskaper om förändringar vad gäller bland annat levnadsförhållanden och inkomstskillnader i befolkningen. Utifrån denna statistik, kombinerat med prisindexförändringar inom olika områden, konstrueras genomsnittshushåll, standardbudgetar etc. En konsekvens av detta är att just genomsnittet får utgöra måttstock, vilket gör att sökljuset sätts på generella förändringar bland befolkningen och inte på specifika grupperingar. I de fall där kategoriseringsförsök ändå görs kvarstår problematiken - genomsnittet i en specifik grupp blir styrande. Ett annat problem med detta perspektiv är att hushållet ur konsumtionshänseende förstås som nyttomaximerande. Här ges inte utrymme för avvikelser, alternativa strategier eller rationaliteter. Konsumtionsmönster och dess villkor är inget statiskt utan något som också bör studeras ur ett dynamiskt perspektiv. Vidare riskerar perspektiven att bli för snäva när inkomster och priser får utgöra de enda intressanta variablerna. Vi får inte heller veta något om vad som döljer sig bakom siffrorna, hur villkoren eller omständigheterna ser ut eller upplevs av de hushåll som ska studeras. Detta behöver inte nödvändigtvis innebära någon kritik mot makroinriktad forskning i sig, utan snarare mot att den har fått ett allt för stort utrymme på bekostnad av mer mikroinriktad kvalitativ forskning.

Det andra huvuddraget handlar om att 
den forskning jag funnit till stora delar begränsar sig till empiriska data. Försöken att teoretiskt förklara olika fenomen eller problem är förhållandevis lätträknade. En möjlig förklaring till detta är att även den amerikanska forskningen, som ofta står som modell till den nordiska inom detta område, till största delen varit empiriskt inriktad. De möjligheter som finns att låta teoribildningar från såväl fattigdoms- eller välfärdsforskningen som konsumtionssociologin befrukta varandra utnyttjas inte. Inom välfärdsforskning finns användbara analytiska begrepp som t.ex. marginalisering, social exclusion, integration vilka kan fördjupa förståelsen av villkoren för ekonomiskt utsatta konsumentgrupper. Från konsumtionssociologin kan resonemang kring konsumtionens symboliska betydelse, konsumtionsmönster, konsumtionsbeteende etc. föra in fler dimensioner i forskningen om ekonomiskt utsatta hushåll. Det finns givetvis fler och alternativa teoretiska wäktenskap" som för detta område skulle kunna generera ny kunskap. Konsumtionsforskning har haft som sitt signum att den bedrivs tvärvetenskapligt, att forskare från olika discipliner samarbetar. Det har emellertid inte alltid inneburit att forskningen teoretiskt fått nya och annorlunda infallsvinklar, åtminstone inte när sökarljuset riktats mot hushåll med knapp ekonomi.

Jag nämnde tidigare att forskningen till stora delar bestod av kvantitativ och makroinriktad forskning. Detta innebär dock inte att det inte förekommer hushållsbaserad forskning. Inom områden som t.ex. skuldsanering och budgetrådgivning, hushållsekonomisk balans och intrafamiljär distribution förekommer det forskning som utgår från hushållet. Ett problem i sammanhanget är emellertid att denna forskning på olika sätt avskärmar hushållet från dess omgivning, vilket utgör det tredje huvuddraget. Flera forskare (t.ex. Klingander 1998, Löfgren 1996, Dellgran 2000, Brusdal 1988a, 1988b) menar att såväl orsaker som lösningar till hushållens konsumtionsproblem även bör sökas i strukturella förhållanden utanför hushållet. Således hade den hushållsbaserade forskningen vunnit i nyansrikedom och förklaringsvärde om den i högre grad undersökte hushållens relationer till omgivningen på olika nivåer. Hur ser de lokala konsumtionsvillkoren ut vad gäller varu- och tjänstemarknaden? Hur ser arbets- och bostadsmarknaden ut? På vilka sätt påverkar olika välfärdsarrangemang situationen på lokal nivå? Samma frågor kan, i modifierad form ställas avseende övriga nivåer, såväl regional som nationell. När det gäller ekonomiskt utsatta hushåll kan det t.ex. vara av värde att få kunskap om deras konsumtionsvillkor och inte enbart om deras ekonomiska manöverutrymme. Finns det faktorer som fördyrar, försvårar, utestänger och hindrar dessa hushåll från att konsumera "rationellt»? Går det att tala om fattigdomsförstärkande processer? Detta har vi idag endast begränsade kunskaper om, men i hitintills gjorda undersökningar har det visat sig att det finns fog för dessa frågor.

Det fjärde huvuddraget handlar om att stora delar av forskningen om ekonomiskt utsatta hushåll i princip enbart diskuterar hushållen i förhållande till olika offentliga välfärdslösningar. Det dominerande perspektivet är ofta hushållens inkomst och hur denna förändras i relation till föränd- 
ringar inom transfereringssystemen och de behovsprövade bidragen. När det gäller skuldsanering och ekonomisk rådgivning är det ofta dessa verksamheter som står i fokus för forskningsintresset. Hushållen studeras i syfte att undersöka huruvida den ekonomiska rådgivningen haft någon effekt och i så fall vilken. Att hushållen är aktörer på den privata tjänste- och varumarknaden är en dimension som inte får speciellt mycket utrymme. Inom senare fattigdomseller välfärdsforskning har man allt mer börjar betona ett dynamiskt perspektiv där bidragshushållen förstås som rörliga aktörer vilka rör sig mellan olika försörjningsalternativ (Walker 1998). Detta synsätt har hitintills inte använts i någon högre utsträckning vad gäller den forskning som riktar in sig mot svaga konsumentgrupper. På vilka sätt agerar dessa grupper i förhållande till varu- och tjänstemarknaden? Vidare har forskningen med inriktning mot ekonomiskt utsatta hushålls konsumtionsvillkor inte i någon större utsträckning försökt belysa de strukturer eller mekanismer som på olika sätt påverkar och styr varu- och tjänstemarknaden. Hur agerar olika aktörer på marknaden i förhållande till ekonomiskt utsatta grupper, går det att skönja några mönster eller strategier för dessa aktörers förhållningssätt? Hur kan man t.ex. förstå företag som använder sig av uthyrning (hyrköp) och olika former av avbetalnings- eller kreditalternativ?

$\AA$ andra sidan har konsumtionssociologin inte intresserat sig speciellt mycket för ekonomiskt utsatta hushåll. Finansiering eller problem med finansiering av konsumtion har inte lyfts fram utan fokus har varit inriktat på olika perspektiv och förståelser av konsumtion som ett kulturellt och socialt fenomen. Intresset har i huvudsak riktats mot andra grupper än de med knapp ekonomi. Visserligen diskuteras på vilket sätt olika faktorer som t.ex. utbildning, civilstånd, yrke och ålder styr och påverkar konsumtionen, men specifika faktorer som fokuserar ekonomisk och/eller social utsatthet används inte i någon högre utsträckning. Ett sätt att förstå de olika sfärer som tillsammans skapar förutsättningar för hushållen är att göra en indelning i stat, marknad och hushåll. ${ }^{6}$ Utifrån en sådan indelning kan man konstatera att fattigdoms- eller välfärdsforskningen i huvudsak intresserat sig för relationen mellan hushåll och stat. Konsumtionssociologin i sin tur studerar relationen mellan hushåll (eller grupper av hushåll) och marknad, där den finansiella eller hushållsekonomiska dimensionen i stort sett lämnas därhän. Forskningsansatser som i en större utsträckning försöker laborera med alla tre sfärerna har en större möjlighet att belysa de konsumtionsvillkor hushållen har att förhålla sig till. Om denna forskning även förhåller sig till såväl själva konsumtionen som finansieringen eller de ekonomiska förutsättningarna för konsumtion skulle detta kunna ge nya kunskaper om hushållen som aktörer i relation till såväl marknad som stat.

6 Begreppet hushåll ersätter i detta sammanhang familj. Även begreppet hushåll är i detta sammanhang problematiskt då det snarare handlar om ett hushålls hela nätverk i form av familj, släkt, vänner, grannar etc., alltså de som inte ryms inom kategorierna stat eller marknad.

Torbjörn Hjort: Forskning om konsumtionsvillkor för hushåll... 


\section{Nordisk vs amerikansk forskning}

Vilka skillnader finner vi vid en jämförelse mellan nordisk forskning om fattigdom och konsumtion och dess amerikanska motsvarighet? Såväl det amerikanska som de nordiska samhällena kan kategoriseras som konsumtionssamhällen. En alltmer multinationell marknadsföring som på olika sätt glider ihop med det mediala utbudet innebär att det är rimligt att anta att de nordiska och amerikanska marknaderna för utbudet av varor och tjänster tenderar att likna varandra alltmer. Medan den amerikanska forskningen sedan lång tid intresserat sig för fattiga gruppers konsumtionsvillkor har detta intresse varit blygsamt ur ett nordiskt perspektiv. Det finns ingen enkel förklaring på hur detta kan komma sig men ett rimligt sätt att börja diskutera skillnaderna är att föra ett resonemang kring välfärdens organisering och vetenskapens undersökning av denna.

Inom Norden har ansvaret för välfärden till största delen varit ett offentligt ansvarstagande. Ett centralt inslag i detta ansvar har handlat om ekonomiska transfereringar av ekonomisk karaktär i ett utjämnande syfte. Detta har också tilldragit sig ett stort intresse för forskningen, som bland annat har fokuserat på huruvida olika offentliga system "lyckats» förbättra inkomstsituationen för olika resurssvaga grupper. Intresset har riktats mot förändring och fördelning av inkomster och den relation som studerats har varit mellan stat/kommun och den enskilde eller hushållet. Den amerikanska organiseringen av välfärd ser annorlunda ut, de offentliga lösningarna spelar en mindre roll och är ofta riktade till de mest utsatta. De privata eller frivilliga insatserna har en mer betydelsefull roll att fylla vilket innebär att forskningen på ett annat sätt intresserat sig för hushållens, även de mer resurssvaga, relation till den "fria» marknaden. Det är i detta sammanhang konsumtionsdimensionen blir intressant. Resurssvaga grupper förstås även de som aktörer på varu- och tjänstemarknaden. Det är inte enbart som mottagare av offentliga lösningar dessa grupper studeras, utan forskningen intresserar sig även för dessa gruppers villkor eller positioner som konsumenter på olika marknadsarenor. Forskning har här visat att konsumtionsvillkoren ser olika ut beroende på vilka hushållsgrupper som undersöks. De resurssvaga grupperna befinner sig som konsumenter i en sårbar position där de ställs inför olika typer av hinder, barriärer och fattigdomsförstärkande mekanismer. Inom nordisk forskning tenderar intresset för resurssvaga gruppers relation till olika marknadsarenor tonas ner till förmån för relationen till offentliga lösningar. För att dra resonemanget till sin spets tycks man utgå från att resurssvaga hushållsgrupper inte har någon relation till varu- och tjänstemarknaden. Åtminstone tycks denna relation inte vara speciellt problematisk eller annorlunda än den andra inkomstgrupper har, när inkomsterna omfördelats är villkoren som konsumenter ungefär desamma för alla.

Hur konsumenter väljer, vilka inomfamiljära processer och vilka preferenser olika kundsegment agerar utifrån är frågor som på olika sätt belyses inom nordisk konsumentforskning. Fokus ligger här följaktligen på subjektiva eller intersubjektiva proces- 
ser, faktiska konsumtionsvillkor undersöks inte. Inom amerikansk forskning har dessa yttre strukturer tilldragit sig ett något större intresse, andra perspektiv dominerar dock fortfarande. Caplovitz (1963), Andreasen (1975), Allwitt \& Donley (1996) och Hill (2002) är några av de amerikanska forskare som visar hur preferenser och konsumtionsmönster inte enbart är ett utslag av smak, önskemål och behov utan att de villkor som resurssvaga konsumenter möter också är betydelsefulla i sammanhanget. Studierna visar vidare hur olika konsumtionsstrategier som vid ett första påseende kan uppfattas som irrationella, kortsiktiga och slösaktiga vid närmare granskning, där hänsyn tas till olika hinder och barriärer, snarare kan uppfattas som rationella eller åtminstone som rimliga nödlösningar.

\section{Avslutning}

Nordisk forskning om ekonomisk utsatthet har hitintills i första hand fokuserat inkomstdimensionen. Villkor och förutsättningar avseende konsumtion har inte undersökts i någon större utsträckning. Den forskning som ur olika perspektiv diskuterar konsumtion och ekonomisk knapphet ställer inte specifika frågor om villkor eller förutsättningar. Trots att samhället tenderar att utvecklas mot ett konsumtionssamhälle saknas kunskaper om hur olika grup- per påverkas. Vi vet att inkomstklyftorna i Sverige har ökat under de senaste fem åren, däremot saknar vi kunskaper om hur differentierade konsumtionsvillkor påverkar resurssvaga grupper vad gäller aspekter som tillgänglighet och pris. En möjlig konsekvens av differentierade konsumtionsvillkor är att grupper med knapp ekonomi hänvisas till förhållanden som innebär bristande tillgänglighet och/eller får betala ett högre pris än andra inkomstgrupper för olika varor och tjänster. När det gäller resurssvaga gruppers konsumtionsförutsättningar handlar det inte enbart om pengar. Jag menar att aspekter som kunskaper och kontakter till vissa delar kan kompensera en knapp ekonomi.

Inom amerikansk forskning förekommer det forskning som belyser fattiga gruppers konsumtionsvillkor. Det finns inga givna svar på varför vetenskapssamhället i Norden inte har uppmärksammat detta forskningsfält. En del av förklaringen ligger förmodligen i skillnader i organiseringen av välfärden och den nordiska forskningens fokusering på hur väl de offentliga systemen "lyckas» lösa sina uppgifter. Även om vi inte okritiskt ska kopiera våra amerikanska kollegers undersökningar är det kanske ändå på tiden att vi börjar ställa frågor om vilka möjligheter och problem det kan innebära att konsumera med knappa resurser i ett överflödssamhälle. 


\section{Referenser}

Aatola, Leena (1992) Possibilities of organizing economy and debt counselling: Survey concerning the possibilities of municipal and private organizations to arrange personal economy and debt counselling. Helsingfors: National Consumer Research Centre. Sammanfattning.

Aatola, Leena \& Viinisalo, Mirja (1995a) The shopping basket as a method to identify living costs - an application. Helsingfors: National Consumer research Centre. Sammanfattning.

Aatola, Leena \& Viinisalo, Mirja (1995b) Defining and measuring reasonable consumption - prospects and problems. Helsingfors: National Consumer Research Centre. Sammanfattning.

Aatola, Leena (1996) Debt counselling in the 1990`s - a voluntary obligation. Helsingfors: National Consumer Research Centre. Sammanfattning.

Alwitt, Linda F. \& Donley, Thomas D. (1996) The low-income consumer - adjusting the balance of exchange. Thousand Oaks: Sage Publications.

Alwitt, Linda F. (1996) "Marketing and the poor" Hill, Ronald Paul (red.) i Marketing and consumer research in the public interest. Thousand Oaks: SAGE Publications.

Andreasen, Alan R. (1975) The disadvantaged consumer. New York: Free Press.

Andreasen, Alan R. (1993) „Revisiting the disadvantaged: old lessons and new problems". Journal of Public Policy\& Marketing. 1993, Fall.

Baudrillard, Jean (1998) The consumer society. London: Sage Publications.

Bauman, Zygmunt (1998) Arbete, konsumtion och den nya fattigdomen. Göteborg: Daidalos.

Bonke, Jens (1997) Hans aegtenskab/hendes aegtenskab. Köpenhamn: Socialforskningsinstituttet 97:15.

Brusdal, Ragnhild (1988a) En kvalitativ studie av hushold i ökonomisk krise. NEK Rapport 1988:2. Köpenhamn: Nordiska Ministerrådet.

Brusdal, Ragnhild (1988b) Husholdsberedskap - En studie av husholdets ökonomi, resurser og beredskap. NEK Rapport 1988:12. Köpenhamn: Nordiska Ministerrådet.
Caplovitz, David (1963) The poor pay more. New York: Free Press.

Dellgran, Peter (2000) „Skuldproblem, ekonomisk rådgivning och skuldsaneringu i Puide, Annika (red.) Socialbidrag $i$ forskning och praktik. Stockholm: Gothia.

Dellgran, Peter \& Karlsson, Niklas (2001) „Konsumtionsmönster och välfärd under 1990talet«. Välfärdens finansiering och fördelning, SOU 2001:57. Stockholm: Fritzes.

Ekström, Karin M. (1995) Childrens' influence in family decision making. Göteborg: BAS.

Gabriel, Yiannis \& Lang, Tim (1995) The unmanageable consumer: Contemporary consumption and its fragmentation. London: Sage Publications.

Halleröd, Björn (1995) »The truly poor: Indirect and direct measurment of consensual poverty in Sweden" Journal of European social policy 5: 111-129.

Halleröd, Björn (1998) „Poor swedes, poor britons: A comparative analysis of relative deprivation" i Andreß, Hans-Jürgen (ed.) Empirical poverty research in a comparative pespective. Aldershot: Ashgate.

Hill, Ronald Paul (2002) "Stalking the poverty consumer - a retrospective examination of modern ethical dilemmas." Journal of business ethics 37.

Hjort, Torbjörn (2000) Konsumtion under knapphet - en nordisk kunskapsöversikt. FRN:s rapportserie 2000:5. Stockholm:FRN.

Horowitz, Daniel (1985) "The morality of spending: attitudes toward the consumer society in America, 1875-1940 «Baltimore: Johns Hopkins Univ. Press.

Jansson, André (2001) Image culture - media, consumption and everyday life in reflexive modernity. Göteborgs Universitet: Department of journalism and mass communication.

Kaufmann Philip R, McDonald James M, Lutz Steve M, Smallwood David M. (1997) Do poor pay more for food? Agricultural Report no. 795. Food and rural economic division. Economic research service, USDepartment of Agriculture. 
Klingander, Birgitta (1995) Hushållets vardagsekonomi. Göteborgs Universitet: Institutionen för slöjd och hushållsvetenskap.

Klingander, Birgitta (1998) Nu är jag kanske stark innerst inne. Göteborgs Universitet: Institutionen för hushållsvetenskap.

Kosunen, Virpi (1999) How much is enough? Assessing the adequacy of basic income security from the point of view of consumption. Helsingfors: National research and development centre for welfare and health. Sammanfattning.

Leiss, William, Klein Stephen \& Jhally Sut (2000)"The bonding of media and advertising" i Lee Martyn J. (red.) The consumer society reader. Oxford: Blackwell.

Löfgren, Orvar (1996) „Konsumtion som vardaglig praktik och ideologiskt slagfältu, i Socialvetenskaplig tidsskrift nr 1-2 1996.

Nyman, Charlotte (1996) "Inside the black box - intrahousehold distribution of consumption in Sweden" i Bihagen Erik, Charlotte Nyman \& Mattias Strand, Three aspects of consensual poverty in Sweden. Umeå studies in sociology no 109. Umeå: Umeå Universitet.

Näsman, Elisabet \& von Gerber, Christina (1996) Mammapappa utanjobb. Stockholm: Rädda Barnen.

Näsman, Elisabet \& von Gerber, Christina (1999) Räkna med oss Norrköping: Linköpings universitet, Institutionen för tematisk utbildning och forskning.

Näsman, Elisabet \& von Gerber, Christina (2001a) Mina pengar! Kan små barn handla själva Norrköping: Linköpings universitet, Institutionen för tematisk utbildning och forskning.

Näsman, Elisabet (2001b) Typ pank! Norrköping: Linköpings universitet, Institutionen för tematisk utbildning och forskning.
Poppe, Christian (1995) Gjeldsrådgivning $i$ kom munerne. Fase 1: En kvalitativ studie av 6 socialkontor. Rapport nr 6:95. Lysaker: SIFO.

Slater, Don \& Tonkiss, Fran (2001) Market society: Markets and modern social theory. Cambridge: Polity.

SOU (1996) Forskning för vår vardag. Konsumentforskningsutredningen, SOU 1996:10. Stockholm: Fritzes

SOU (2000) Välfärd vid vägskäl. SOU 2000:3. Stockholm: Fritzes

SOU (2001) Välfärdens finansiering och fördelning SOU 2001:57. Stockholm: Fritzes.

Stjernö, Steinar (1985) Den moderne fattigdommen. Oslo: Universitetsforlaget.

Tufte, Per Arne (1992) Holdninger till lov om gjeldsordning for privatpersoner. Rapport $\mathrm{nr}$ 3:92. Lysaker: SIFO.

Tufte, Per Arne (1993) Velkommen til velferdsstaten? Et rettferdighetsperspektiv på gjeldsordningsloven. Rapport nr 3:93. Lysaker: SIFO.

Waerstad, K. (1994) Offentlig ökonomisk rådgivning. En evaluering av prosjektet "Forbukernes ökonomiske rådgivningstjeneste«. Rapport $\mathrm{nr}$ 13:94. Lysaker: SIFO.

Waerstad, K. (1995) Interkommunal gjeldsrådgivning. En evaluering av försöksprosjektet "Gjeldsrådgivning for Midt-Gudbrandsdal«. Rapport nr 5:95. Lysaker: SIFO

Walker, Robert (1998) »Rethinking poverty in a dynamic perspective« i Andreß, Hans-Jürgen (red.) Empirical poverty research in a comparative pespective. Aldershot: Ashgate.

Wilska, Terhi-Anna (1995) Born to be consumers? Åbo: Publications of the Turku school of economics and business administration. 


\section{Summary}

\section{Research on low-income households' conditions for consumption. A poorly developed field}

Nordic research on poverty has not highlighted consumption in any specific sense. In a society with increasing gaps in income and with more pressure to consume, it makes sense to ask questions about how economically vulnerable groups are affected. Is there a risk that a variety of conditions increases economic hardship for poor households? This article discusses the Nordic research that focuses on consumption and poverty. Five research themes are presented and discussed in a critical way: (1) standard budgets and their relation to constructions of subsistence level; (2) the problems of overdebtedness; (3) consumption as an indicator of welfare; (4) households' strategies to make ends meet; (5) distribution of resources inside the family. The article then discusses these five themes in a more critical way. There are four fundamental features that can be problematic. The first one is that a large part of the studies take their starting point at a macro-level. This means that we just obtain knowledge about the average, not the deviation. We do need quantitative knowledge, but not at the expense of studies that try to uncover what is behind the statistics. The second one is that most of the studies are restricted in principle to empirical data. The efforts to theoretically explain the studied phenomenon are rather few. The potential to combine theories and concepts from both disciplines, research on poverty and sociology of consumption, is seldom utilized. The third fundamental feature focuses on the studies at micro-level. Households seem to be understood as an isolated island, with no examination of their relations to other arenas such as the labour market, the state and the market for goods and services. The fourth feature is about the problem that most of the studies on poverty principally deal with the relation between the state and the household. The fact that poor households also are actors on the market for goods and services seems to be neglected. 